\section{THE DAY RANGe AND HOME RANGE OF the EASTERN HOOLOCK GibBon Hoolock leuconedys (MAMmalia: Primates: Hylobatidae) in Lower Dibang Valley District in Arunachal Pradesh, INDia}

\author{
Kuladip Sarma ${ }^{1}$ \& Awadhesh Kumar ${ }^{2}$
}

1,2 Department of Forestry, NERIST, Nirjuli, Itanagar, Arunachal Pradesh 791109, India

${ }^{1}$ Present address: Centre for Animal Ecology \& Wildlife Biology, Department of Zoology, Gauhati University, Guwahati, Assam 781014, India

${ }^{1}$ kldpsarma306@mail.com, ${ }^{2}$ tpileatus@gmail.com (corresponding author)

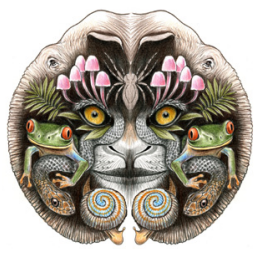

ISSN $0974-7907$ (Online) ISSN 0974-7893 (Print)

OPEN ACCESS

\begin{abstract}
This paper presents the findings of a study conducted on the Eastern Hoolock Gibbon Hoolock leuconedys in Mehao Wildlife Sanctuary and outside to the south of the park, Arunachal Pradesh, India investigating the daily path length (DPL) and home range used by the species in two forest areas with different disturbance gradients. The four habituated groups of $\mathrm{H}$. leuconedys in fragmented and contiguous forest areas, two groups in each of the forest types, showed considerable variation in their DPL ranging from 6.59m to $1019.01 \mathrm{~m}$ with a mean distance of $192.75 \mathrm{~m}(\mathrm{SE}= \pm 26.48)$ in 73 full day observations. Although the mean DPL was recorded with very little variation across the seasons in both the forest types, it was significantly different from fragmented forest. Similarly, the home range size also varied among the groups and was estimated as the maximum for Group D (24.62ha) followed by Group E (16.28ha) in contiguous forest and Group $B(2.49 \mathrm{ha})$ and Group A (1.09ha) in fragmented forest. Also, there was a distinct seasonal pattern of home range used by all the study groups with largest seasonal home range in monsoon and pre-monsoon season in fragmented and contiguous forest respectively. The DPL and home range of $\mathrm{H}$. leuconedys in Arunachal Pradesh has been highly affected by forest fragmentation and/or canopy discontinuity which makes the species vulnerable to hunting, predation by feral dogs and hawks and ultimately local extinction. Thus, the findings of the present research evoke the question of long term survival of the species in fragmented forests.
\end{abstract}

Keywords: Contiguous forest, fragmented forest, Mehao Wildlife Sanctuary, movement pattern.

DOI: http://dx.doi.org/10.11609/jott.2739.8.4.8641-8651

Editor: Mewa Singh, University of Mysore, Mysuru, India.

Date of publication: 26 April 2016 (online \& print)

Manuscript details: Ms \# 2739 | Received 27 March 2015 | Final received 30 March 2016 | Finally accepted 02 April 2016

Citation: Sarma, K. \& A. Kumar (2016). The day range and home range of the Eastern Hoolock Gibbon Hoolock leuconedys (Mammalia: Primates: Hylobatidae) in Lower Dibang Valley District in Arunachal Pradesh, India. Journal of Threatened Taxa 8(4): 8641-8651; http://dx.doi.org/10.11609/jott.2739.8.4.8641-8651

Copyright: @ Sarma \& Kumar 2016. Creative Commons Attribution 4.0 International License. JoTT allows unrestricted use of this article in any medium, reproduction and distribution by providing adequate credit to the authors and the source of publication.

Funding: NRDMS Division, Department of Science \& Technology \& CSIR, Govt. of India for providing Senior Research Fellowship Grant to the fisrt author.

Conflict of Interest: The authors declare no competing interests.

Author Contribution: KS has collected data, did the analysis and drafted the manuscirpt. AK did the final analysis and finalized the manuscript.

Author Details: DR. KULADIP SARMA has completed his doctoral research on ecology of eastern hoolock gibbon from Department of Forestry, NERIST and currently pursuing his post-doctoral research from University of Gauhati. He is interested on ecoloical conservation of threatened mammals of northeastern India. DR. AWADHESH KUMAR, an Associate Professor, Department of Forestry, NERIST has been working on primates and other threatened mammals of northeastern India. His interest lies in ecological processes related to wildlife and forest management under the umbrella of forestry research.

Acknowledgement: The authors express their sincere thanks to the PCCF-Wildlife, Itanagar for giving necessary permission to carry out this extensive research. We are thankful to Director, NERIST (Deemed University), Nirjuli and Head of Department, Forestry for their administrative and academic support. We are thankful to Biranjoy Basumatary and Akhetu Mendo for assisting in the field during data collection. Also, we are grateful to the reviewers and the editor, JoTT for their suggestions to improve the quality of the manuscript. Finally, we are very much thankful to NRDMS, Department of Science and Technology and CSIR, Govt. of India for financial support to carry out this research work.
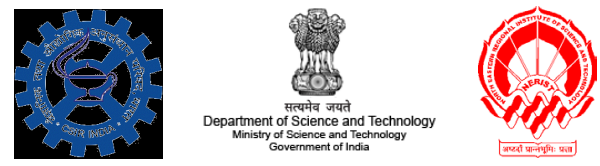


\section{INTRODUCTION}

Movement patterns in primate groups are restricted to a limited area and they are highly influenced by the distribution of resources in time and space (Milton 1980; Sigg \& Stolba 1981). The patchy distribution of fruits and their abundance in any forest at a given time has a major impact on the ranging behaviour of frugivorous primates. Also, the degree of frugivory, behavioural and dietary plasticity and the ability to utilize the matrix habitat are the key features which decide whether primates can live in forest fragments (Estrada \& CoatesEstrada 1996; Lovejoy et al. 1996; Tutin \& White 1999; Onderdonk \& Chapman 2000; Marsh 2003). Essentially, the range requirement of a particular primate species influences the survival rate in forests of different disturbance gradients. For example, primates with small home ranges may survive better in fragments than those with large range requirements; on the contrary home range dispersion pattern of a species might be altered in a fragment (Kakati 2004). Other factors cited as potential determinants of ranging behaviour in primates include rainfall (Olupot et al. 1997), group size (Ostro et al. 1999), reproductive condition (Overdorff 1993), water availability (Chapman 1988), locations of sleeping sites (Harrison 1983), intergroup relationships (Kinnaird 1992), and parasite avoidance (Hausfater \& Meade 1982).

The genus Hoolock comprises two distinct species, the Eastern Hoolock Gibbon Hoolock leuconedys and the Western Hoolock Gibbon Hoolock hoolock which have been separated based on differences in fur coloration (Mootnick \& Groves 2005; Geissmann 2007). Hoolock leuconedys was earlier known to be distributed east of the Chindwin River to the Salween River in Myanmar and southwestern Yunnan Province in China at an altitudinal range of $1067 \mathrm{~m}$ to $1219 \mathrm{~m}$ (Groves 1971) until it was reported from Arunachal Pradesh, India by Das et al. (2006). Hoolock leuconedys has been reported to occur in India between the Lohit River in the north and the high altitude mountain of Dafa bum in the south (Das et al. 2006). The species, however, was reported from the lower Dibang Valley (Chetry et al. 2008) and Mehao Wildlife Sanctuary (Chetry et al. 2010). Recently, the species was also found to occur in Sadiya Division, the easternmost part of Assam, south of DibangBrahmaputra River system (Chetry \& Chetry 2010).

The Hoolock Gibbon is a territorial species with a group occupying a home range area of 22-35 ha in size on average, and defending a major part of it (77-95\%) as an exclusive territory (Tilson 1979; Gittins \& Akonda
1982; Ahsan 1994; Alfred \& Sati 1990; Feeroz \& Islam 1992). Das (2002) and Kakati (2004) have studied the home range of Hoolock hoolock in different disturbance gradients with special reference to northeastern India. Kakati $(1997,2004)$ has addressed the impact of fragmentation on range use of $H$. hoolock in various forest fragments of Assam. Further, Kakati (1997) stated that gibbon groups in a small fragment occupy small home ranges (4.8ha and 7.1 ha) resulting chiefly from the groups being unable to access several pockets of trees due to the discontinuous canopy. Other studies reported were merely on the comparison of the home range size of two or more groups in the same habitat (Ahsan 2004). While among the other gibbon species of Southeast Asia, Lar Gibbon is the most studied (Raemaekers 1979; Bartlett 1999, 2009) followed by Kloss's Gibbon (e.g., Whitten 1982) and others (e.g., Ganas \& Robbins 2005; Zhou et al. 2007; Kim et al. 2011). A few studies were carried out on the genus Hoolock to document its ranging pattern in Bangladesh, China and India (Feeroz \& Islam 1992; Ahsan 2001; Kakati 1997, 2004; Das 2002; Fan et al. 2013), although the range use pattern of $H$. leuconedys has not been studied in India earlier. This study, therefore, emphasizes the ranging behaviour of $H$. leuconedys in two habitats of different disturbance gradients and different sizes.

\section{Study Sites and Study Groups}

The present study was conducted in Mehao Wildlife Sanctuary (MWS) near the southern boundary and outside the sanctuary at Horupahar and Delo area in Lower Dibang Valley District of Arunachal Pradesh (Fig. 1). MWS covers an area of $282 \mathrm{~km}^{2}$ whereas the lower reaches of the sanctuary which is an Unclassified State Forest covers c. $500 \mathrm{~km}^{2}$ area including Horupahar and Delo. Four social groups of Eastern Hoolock Gibbon were selected for the study, two in MWS which has a contiguous forest and two in Horupahar and Delo areas which are characterized by fragmented forests. The fragmented forest areas are located outside MWS and are 5-7 km away from the southern boundary of MWS. These sites are unclassified forests and lie between

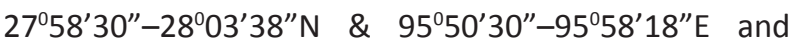
altitude ranges from 145-390 $\mathrm{m}$ (Fig. 1). The major forest types recorded in the area are low hills and plains semievergreen forest, Assam alluvial plains semi-evergreen forest $2 \mathrm{~B} / \mathrm{Cla}$ and sub Himalayan light alluvial evergreen forest 2B/CI/ISI (Kaul \& Haridasan 1987; Champion \& Seth 1968).

Field work was carried out from October 2010 to March 2013. A preliminary population census and 

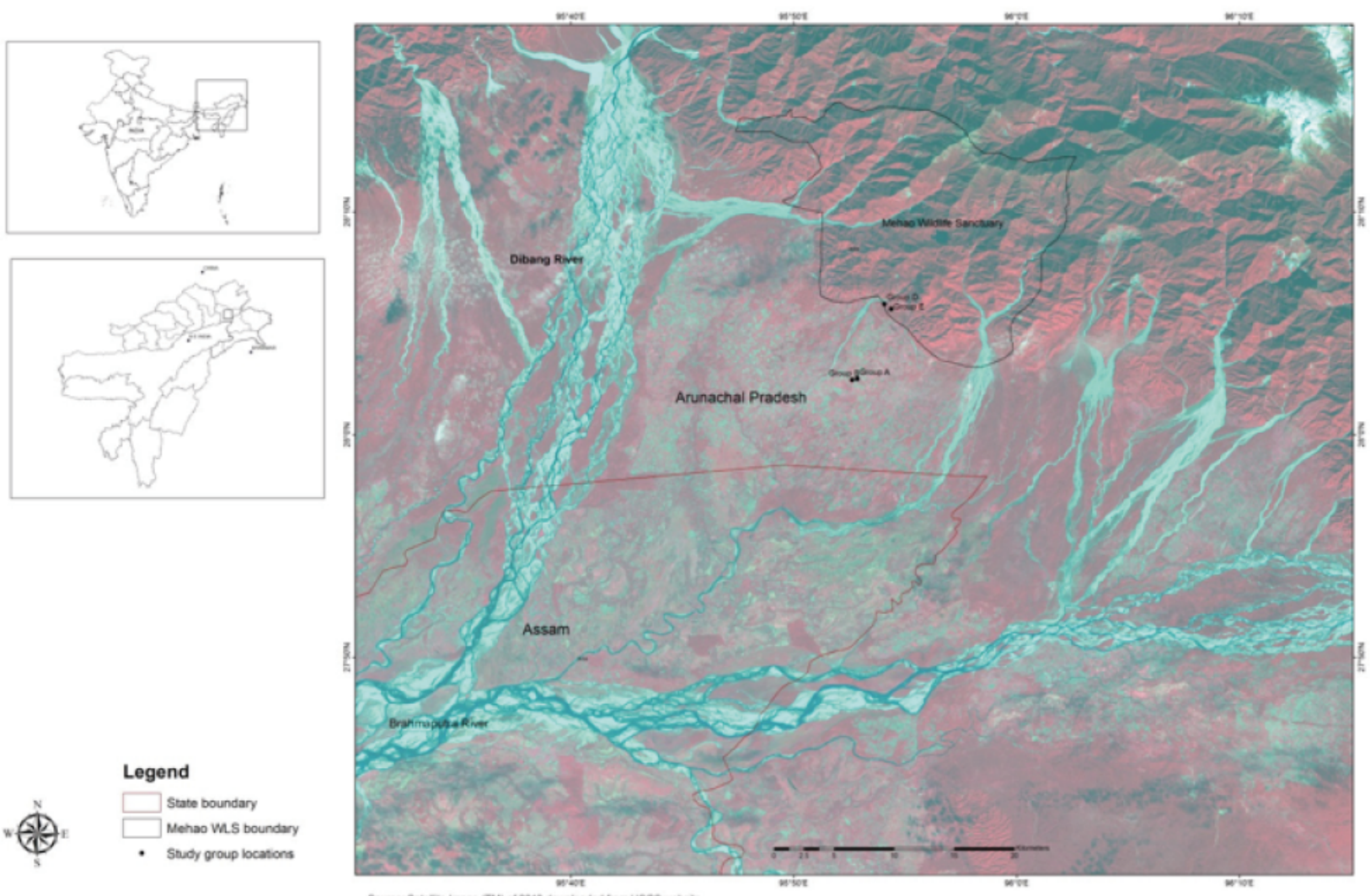

Figure 1. Map of the study area showing the locations of study groups.

distribution survey commenced prior to the selection of gibbon groups for behavioural observations (e.g., Sarma et.al. 2015). Four Eastern Hoolock Gibbon social groups, viz., Group A and Group B in fragmented forest patches and Group D and Group E in contiguous forest patches with the home range in the study area were habituated and selected for intensive study (Images 1-6). The detailed age-sex composition of the study groups is presented in Table 1. The intensive study was conducted between January 2012 and February 2013.

\section{METHODS}

The locations of the focal animals during travel and feeding were taken with a hand held Garmin e-Trex 30 global positioning system (GPS), set to the WGS 84 grid system. During the location sample, the tree occupied by the focal animal was marked by flagging tape and subsequently relocated and mapped relative to the trail system using $30 \mathrm{~m}$ measuring tape and compass. The location sample of the known feeding and lodging trees were also combined with the 30 minutes location samples and the home range size was calculated using the home range module of ArcGis 9.3 by drawing a minimum convex polygon around the cumulative day ranges of each social group. Same location samples in a given day were discarded and not used in the analysis. Groups in contiguous forests were followed for 11 months each (31 full days) as it was difficult to find gibbons because of the large home range and a low frequency of calling (Zhang et al. 2014). However, the two study groups in fragmented forests were followed for a consecutive 12 months ( 42 full days) as the topography was quite accessible. The sample size was comparable to most gibbon studies regarding ranging patterns (Gittins 1982; Whitten 1982; Islam \& Feeroz 1992; Ahsan 2001; McConkey \& Chivers 2007; Bartlett 2009; Fan \& Jiang 2008; Kim et al. 2011) and other primate studies (Kaplin 2001; Zhou et al. 2007). The locations and duration of all group encounters and vocalizations were recorded in field notebooks.

\section{Data Analysis}

The Daily Path Length (DPL) was calculated from full-day observations ( $N=73$ ) as the sum of the straightline distances (in meters) between consecutive GPS points via Arc Map 9.3. Later, the home range size was 


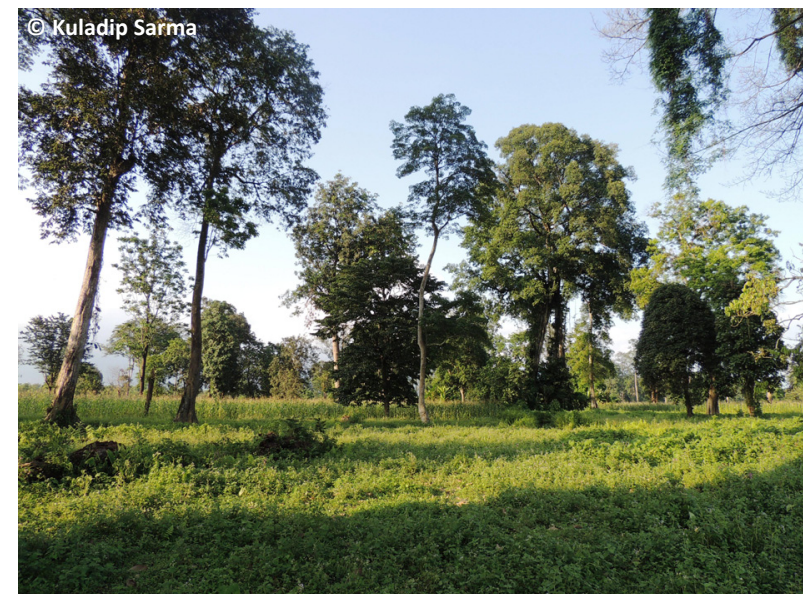

Image 1. Fragmented habitat.

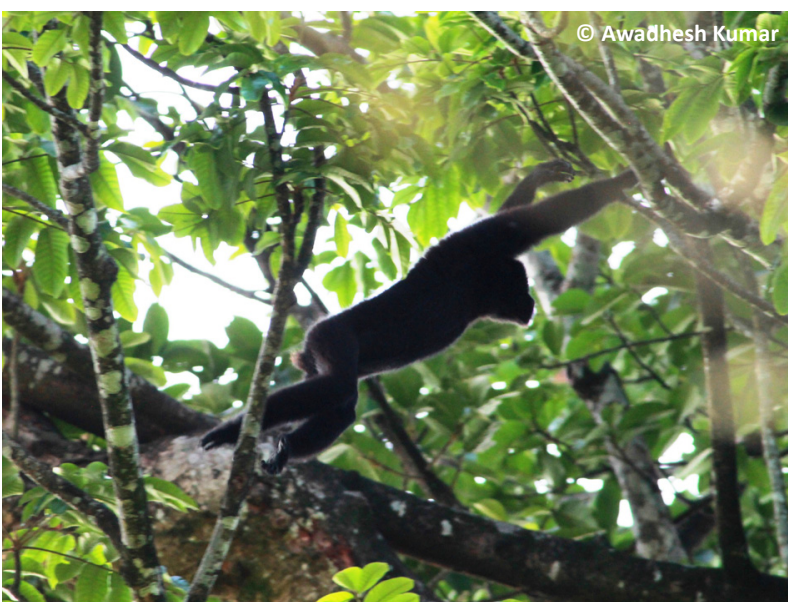

Image 3. Adult male gibbon walking on branch during dispersal.

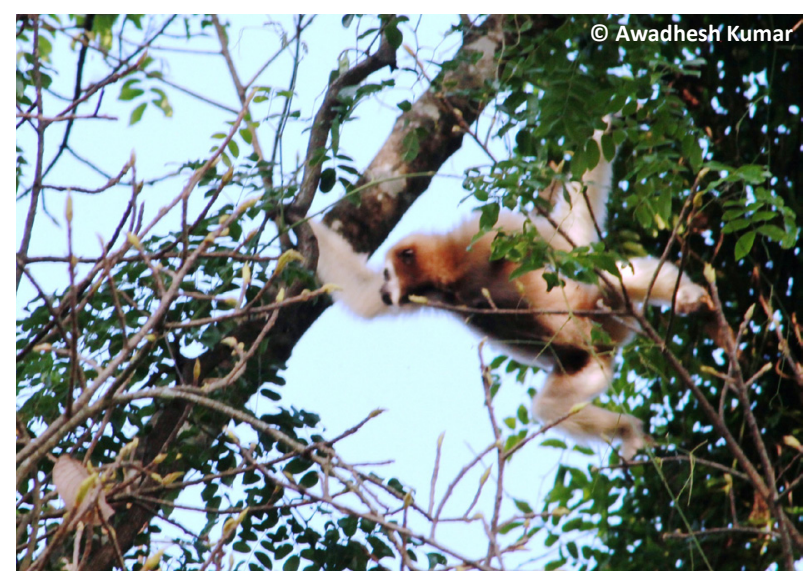

Image 5. Adult female on dispersal mode.

calculated in Arc Map 9.3. using an extension tool home range by drawing minimum convex polygon around the cumulative day ranges of each study group. The total

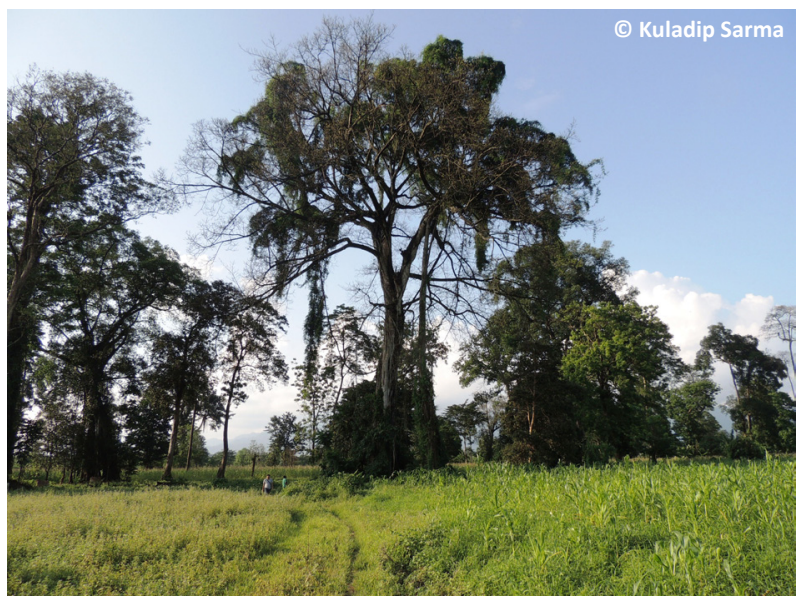

Image 2. Fragmented habitat surrounded by agriculture field.

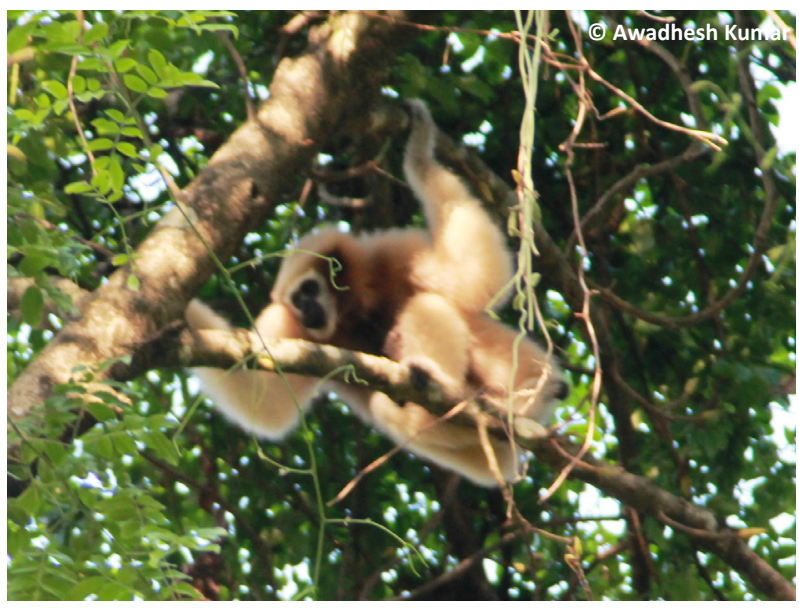

Image 4. Adult female gibbon resting during mid-day.

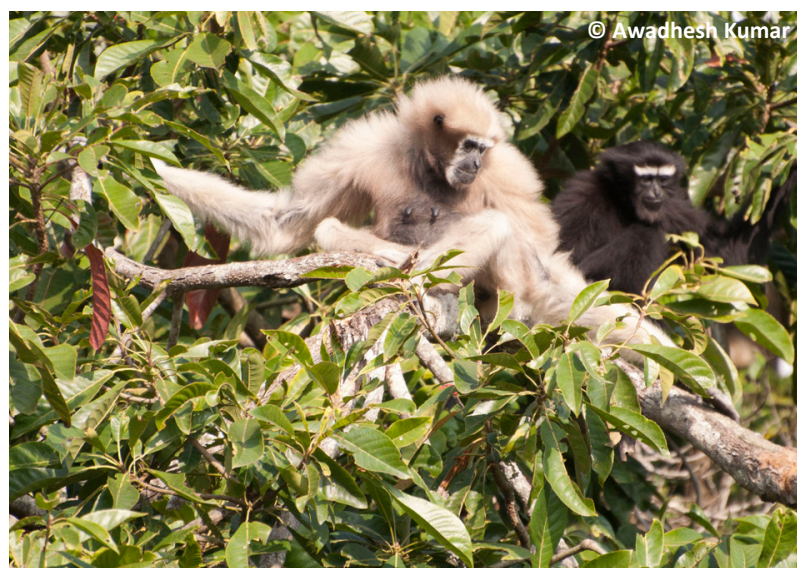

Image 6. Adult male and female resting together during mid-day.

home range is defined here as the area included within a minimum convex polygon encompassing all locations recorded in each seasons (seasonal home range size) 
Table 1. Group structure of the selected study groups of $\boldsymbol{H}$. leuconedys.

\begin{tabular}{|c|c|c|c|c|c|c|c|c|}
\hline Forest quality & Group ID & $\begin{array}{l}\text { Total no. of } \\
\text { individuals }\end{array}$ & \multicolumn{6}{|c|}{ Age/sex composition } \\
\hline Contiguous & Group-E & 3 & 1 & 1 & - & - & - & 1 \\
\hline Fragmented & Group-A & 3 & 1 & 1 & - & - & - & 1 \\
\hline Total & & 11 & 4 & 4 & - & - & - & 3 \\
\hline
\end{tabular}

and throughout the study (total home range size) (e.g., Kaplin 2001; Zhang et al. 2014). Home range and DPL were analysed in four seasons, viz., Winter (DecemberFebruary), Pre-monsoon (March-May), Monsoon (June-September) and Retreating monsoon (OctoberNovember) following Borthakur (1986). All statistical analyses were performed using SPSS 16.0 for Windows.

\section{RESULTS}

\section{Daily path length}

The daily path length (DPL) of the four study groups varied from $6.59 \mathrm{~m}$ to $1019.01 \mathrm{~m}$ with a mean distance of 192.75m (SE $= \pm 26.48$ ) (Table 2). However, DPL was significantly different among the four groups $(F=49.79$; $\mathrm{df}=3 ; \mathrm{p}<0.01)$ and it was much smaller in fragmented forests (mean $=37.42 ; \mathrm{SE}= \pm 3.86$ ) in comparison to that of contiguous forests ( mean $=410.21$; $\mathrm{SE}= \pm 36.01$ ). Although, the mean DPL was recorded with very little variation across the seasons in both the forest types (Table 3), it was significantly different in fragmented forest $(F=3.54 ; d f=3 ; p<0.05)$. The mean DPL of the four study groups was found to be the highest in the pre-monsoon season (237.82; SE $= \pm 61.58$ ) followed by the monsoon (231.60; $\mathrm{SE}= \pm 66.51$ ) and the retreating monsoon seasons (175.21; $\mathrm{SE}= \pm 50.90)$. The lowest DPL was recorded in the winter season $(130.95 ; \mathrm{SE}= \pm 28.93)$ (Fig 2).

\section{Home range size}

The Home range size greatly varied among the groups and the estimated maximum size was for Group D (24.62ha) followed by Group E (16.28ha) in contiguous forests and Group B (2.49ha) and Group A (1.09ha) in fragmented forests (Figs. 3a \&3b). Both the home range size and DPL were found to be higher in contiguous forests in overall estimates in a year (Fig 4). The home range estimated seasonally was found to be

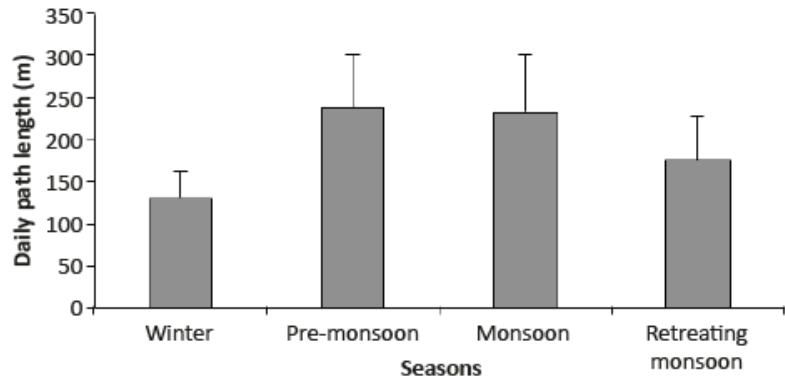

Figure 2. Total daily path length across different seasons of the year.

Table 2. Mean of daily path length (DPL) with minimum and maximum values of four study groups in fragmented and contiguous forests.

\begin{tabular}{|l|c|c|c|}
\hline Groups* & Mean DPL $(\mathrm{m}) \pm$ SE & Minimum & Maximum \\
\hline \multicolumn{5}{|l|}{ Fragmented forest } \\
\hline Group A & $36.09 \pm 5.85$ & 6.59 & 96.64 \\
\hline Group B & $38.75 \pm 5.15$ & 7.36 & 115.46 \\
\hline Average & $37.42 \pm 3.86$ & 6.98 & 106.05 \\
\hline Contiguous forest & \multicolumn{5}{|l}{} \\
\hline Group D & $440.67 \pm 65.03$ & 169.27 & 1019.01 \\
\hline Group E & $375.40 \pm 21.14$ & 266.19 & 531.32 \\
\hline Average & $410.21 \pm 36.01$ & 217.73 & 775.17 \\
\hline Total & $192.75 \pm 26.48$ & 6.59 & 1019.01 \\
\hline
\end{tabular}

*ANOVA; $F=49.79 ; \mathrm{df}=3 ; \mathrm{p}<0.01$

the highest during the monsoon season by both groups in fragmented forests (0.58ha for group A and 1.59ha for group B), whereas in contiguous forests, the home range in the pre-monsoon season was found to be the highest for both the groups D and E (11.78ha and 9.53ha respectively) (Table 4). The seasonal home range was found to be significantly different among the groups (Chi square $=11.41 ; \mathrm{df}=3 ; \mathrm{p}<0.05$ ). 

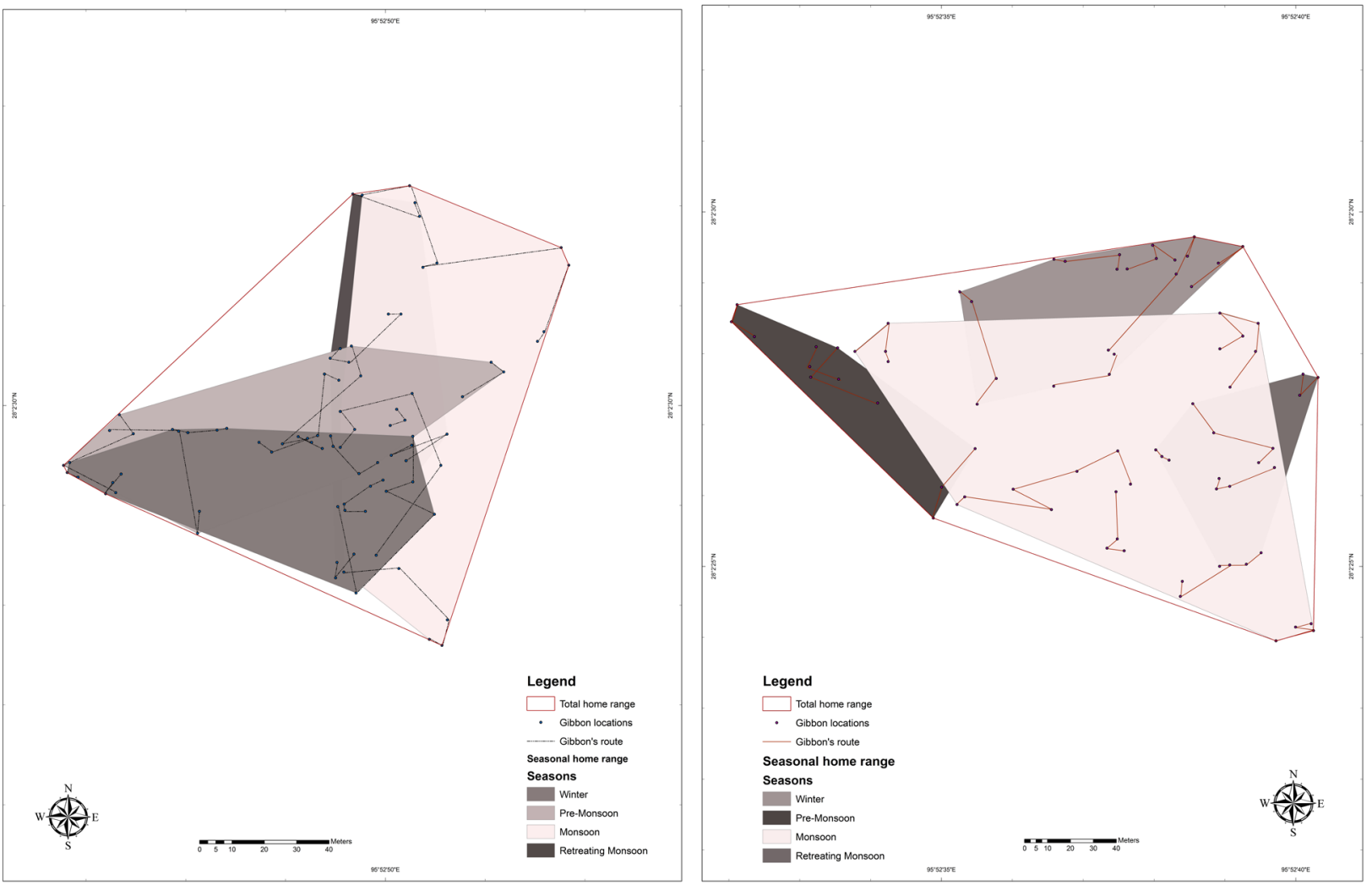

Figure 3a. Home range of Group A (left) and Group B (right) showing seasonal pattern in different shades.
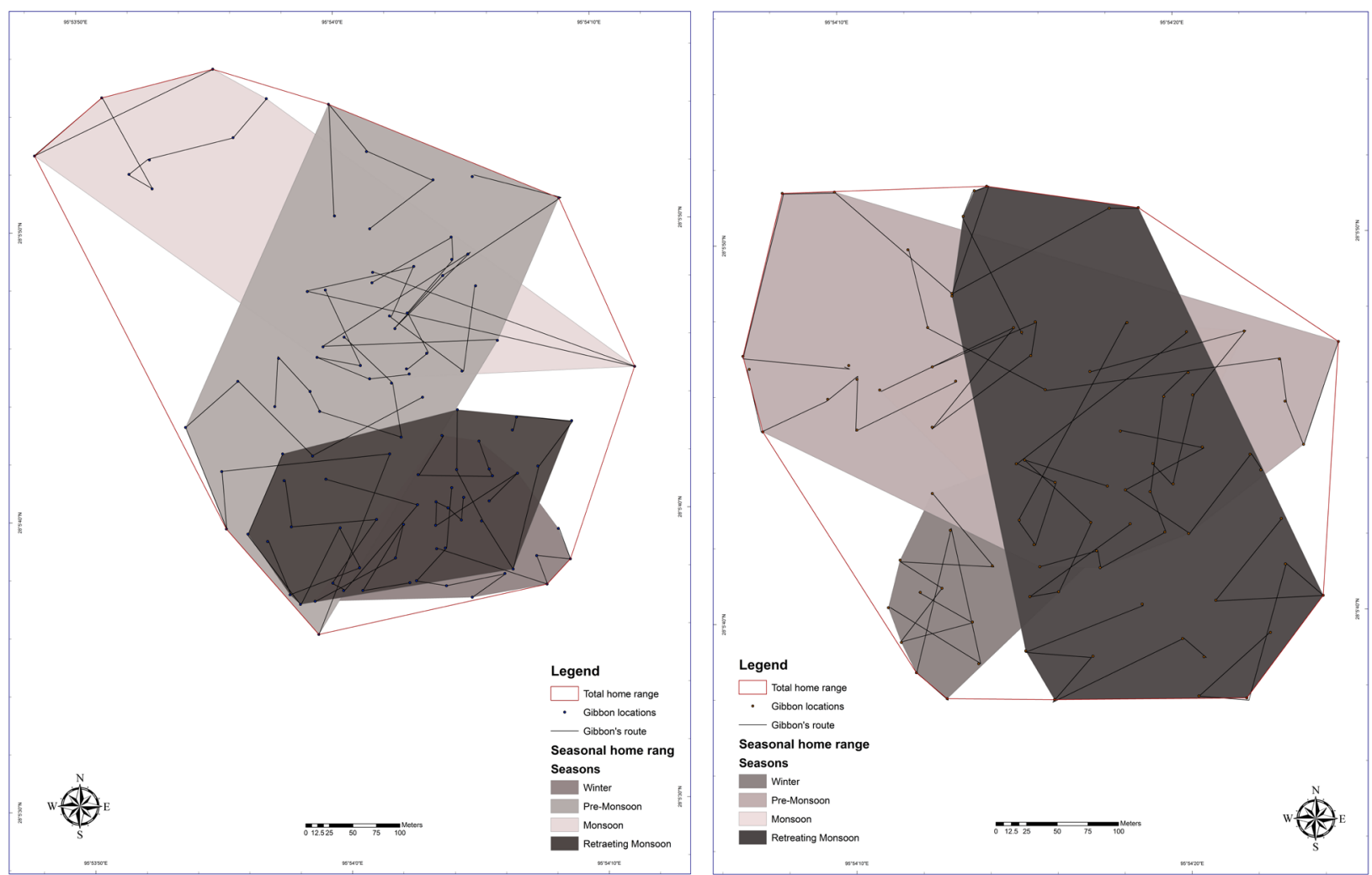

Figure 3b. Home range of Group D (left) and Group E (right) showing seasonal pattern in different shades. 
Table 3. Mean daily path length (DPL) in fragmented and contiguous forests across the seasons of the year.

\begin{tabular}{|c|c|c|c|}
\hline Season & Mean DPL \pm SE & Minimum & Maximum \\
\hline \multicolumn{4}{|l|}{ Fragmented forest } \\
\hline Winter & $34.84 \pm 7.74$ & 6.59 & 96.64 \\
\hline Pre-Monsoon & $35.32 \pm 4.46$ & 18.29 & 58.52 \\
\hline Monsoon & $56.11 \pm 9.97$ & 24.91 & 115.46 \\
\hline Retreating Monsoon & $23.91 \pm 4.10$ & 7.36 & 47.66 \\
\hline Overall mean & $37.42 \pm 3.86$ & 6.59 & 115.46 \\
\hline \multicolumn{4}{|l|}{ Contiguous forest } \\
\hline Winter & $275.10 \pm 24.32$ & 169.27 & 362.03 \\
\hline Pre-Monsoon & $462.81 \pm 77.25$ & 266.19 & 883.56 \\
\hline Monsoon & $482.30 \pm 103.08$ & 239.44 & 1019.01 \\
\hline Retreating Monsoon & $427.36 \pm 18.06$ & 348.39 & 467.31 \\
\hline Overall mean & $410.21 \pm 36.01$ & 169.27 & 1019.01 \\
\hline
\end{tabular}

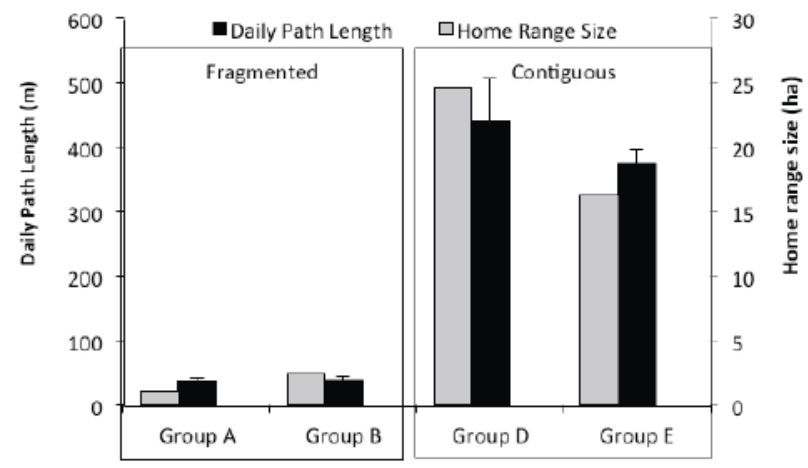

Figure 4. Daily path length and home range size of four study groups.

Table 4. Seasonal home range, estimated by minimum convex polygon method, used by $\boldsymbol{H}$. leuconedys groups and their percentage contribution to total home range.

\begin{tabular}{|l|c|c|c|c|c|c|c|c|}
\hline \multirow{2}{*}{ Seasons } & \multicolumn{2}{|c|}{ Group A } & \multicolumn{2}{|c|}{ Group B } & \multicolumn{3}{c|}{ Group D } & \multicolumn{2}{c|}{ Group E } \\
\cline { 2 - 10 } & $\begin{array}{c}\text { Home } \\
\text { Range (ha) }\end{array}$ & $\begin{array}{c}\text { \% Contribution } \\
\text { to total home } \\
\text { range }\end{array}$ & $\begin{array}{c}\text { Home Range } \\
\text { (ha) }\end{array}$ & $\begin{array}{c}\text { \% Contribution } \\
\text { to total home } \\
\text { range }\end{array}$ & $\begin{array}{c}\text { Home } \\
\text { Range (ha) }\end{array}$ & $\begin{array}{c}\text { \% Contribution } \\
\text { to total home } \\
\text { range }\end{array}$ & $\begin{array}{c}\text { Home } \\
\text { Range (ha) }\end{array}$ & $\begin{array}{c}\text { \% Contribution } \\
\text { to total home } \\
\text { range }\end{array}$ \\
\hline Winter & 0.31 & 28.70 & 0.44 & 17.79 & 2.84 & 11.53 & 2.15 & 13.23 \\
\hline Pre-monsoon & 0.36 & 33.06 & 0.26 & 10.53 & 11.78 & 47.84 & 9.53 & 58.53 \\
\hline Monsoon & 0.58 & 53.47 & 1.59 & 63.81 & 9.35 & 37.99 & 3.29 & 20.24 \\
\hline Retreating monsoon & 0.26 & 23.59 & 0.30 & 12.09 & 4.95 & 20.09 & 8.40 & 51.59 \\
\hline
\end{tabular}

\section{DISCUSSION}

The results of the present study have shown that the daily path length of the groups in fragmented forests is much shorter than that in contiguous forests. The reason may be distantly located forest patches which make dispersal of the gibbon more troublesome in fragmented forests in particular. Severe canopy loss in the fragmented forests in Lower Dibang Valley district had been reported by Sarma et al. (2015). Similar results have also been reported for $\mathrm{H}$. hoolock in other distribution ranges (Kakati 2004). She reported a minimum of 654 $\mathrm{m}$ day range in smaller fragments and a maximum of $1513 \mathrm{~m}$ in large fragments. Furthermore, she stated that low fruit abundance in those disturbed habitats caused the shorter day range. A similar observation was also reported by Fan et al. (2013) on $\mathrm{H}$. leuconedys in China who stated that $\mathrm{H}$. leuconedys in such situations might switch their diet from fruit to leaves. Thus, besides canopy loss, food abundance, distribution and dietary preferences might also have a correlation with shorter
DPL like in the case of many other primates (Janson \& Goldsmith 1995; O’Brien \& Kinnaird 1997; Olupot et al. 1997; Ganas \& Robbins 2005), though some other studies have discarded this hypothesis (e.g., GautierHion et al. 1988; Buzzard, 2006).

Several other articles on frugivorous primate species including gibbons have emphasized on fruit availability (Cercocebus albigena: Olupot et al. 1997; Ateles chamek: Wallace 2006; Nomascus concolor: Fan \& Jiang 2008; Hylobates lar: Bartlett 2009), both on the spatial and temporal scales as an important determinant of change in DPL (Kaplin 2001). Moreover, other factors like territorial defense, resource monitoring and even insect prey abundance may also have a profound effect on the ranging pattern (e.g., DiFiore 2003; Buzzard 2006). Therefore, it will not be conclusive to state that canopy discontinuity was the only cause of shorter DPL in the study groups. A more systematic study integrating all the above mentioned factors is of utmost necessity to understand the matter clearly. Furthermore, the mean DPL calculated for both fragmented and contiguous 
forests in the present study was much shorter $(192.75 \mathrm{~m})$ than other studies carried out on the genus Hoolock in lowland forests as well as montane forests of china (Zhang et al. 2014).

It was also noted that the DPL was found to be the highest during the monsoon season in both fragmented and contiguous forests. This result may not have been affected by the availability of food resources alone. The fragmented as well as the contiguous forest patches are located nearby human habitation and experiences a high degree of anthropogenic pressure (Sarma 2015). However, in the present study it was observed that human activities were minimal during the monsoon season and that might have allowed the study groups to access more area for foraging. The shortest DPL observed during the winter season is in conformation with ranging patterns reported for White-handed Gibbons in KhaoYai National Park (Bartlett 1999). On the contrary, other studies carried out on $\mathrm{H}$. hoolock argued that the winter season holds the longest DPL of the species (Das 2002).
The quality and productivity of the habitat often determines the home range size (Laundre \& Keller 1984) and thus home range is guided by feeding habits (Ellefson 1974) as well as local anthropogenic factors (Das 2002). Further, Sarma et al. (2015) stated that gibbons were also found to survive on a single tree surrounded by agriculture fields and mostly in forest patches having more than seven tree individuals. In the present study, gibbons were mostly observed to feed on fig species which are abundant in the study area.

The ranging pattern may be affected by the habitat quality because primates have less foraging options in fragmented habitats (Poulsen et al. 2001) which essentially influence animal movement (Morales et al. 2010). Generally, gibbon home ranges average approximately 34 ha with some as large as 50 ha (Chivers 1984). In this context, the home range size of the two study groups is very small (1.09ha for Group A and 2.49ha for Group B) in fragmented forests, however, this finding is comparable with those of other studies of $H$.

Table 5. Summary of information on Hoolock Gibbon daily path length and home range size. Numbers indicate mean values (and range of values). Also cited in Geissmann et al. 2013.

\begin{tabular}{|c|c|c|c|c|c|}
\hline \multirow[b]{2}{*}{ Study sites } & \multicolumn{2}{|c|}{ Sample size } & \multirow{2}{*}{$\begin{array}{l}\text { Daily path length } \\
\text { (DPL) (m) }\end{array}$} & \multirow[b]{2}{*}{ Home range (ha) } & \multirow[b]{2}{*}{ Source } \\
\hline & $\begin{array}{l}\text { No. of groups } \\
\text { observed }\end{array}$ & Study duration & & & \\
\hline \multicolumn{6}{|l|}{ Western Hoolock Gibbon ( $H$. hoolock) } \\
\hline Chunati WS, Bangladesh & 1 & 24 months & - & 25.7 & Ahsan 2001 \\
\hline Rajkandi, Bangladesh & - & 5 months & - & 23.0 & Gittins \& Tilson 1984 \\
\hline West Bhanugach, Bangladesh & 2 & 2 months & - & $10.6(3.2-18)$ & $\begin{array}{l}\text { Gittins } 1980 \text { cited in } \\
\text { Gittins \& Tilson } 1984\end{array}$ \\
\hline West Bhanugach, Bangladesh & 1 & 12 months & $1200(600-1600)$ & $35(30-35)$ & $\begin{array}{l}\text { Feeroz \& Islam 1992; } \\
\text { Islam \& Feeroz } 1992\end{array}$ \\
\hline West Bhanugach, Bangladesh & 2 & 24 months & $1367^{\mathrm{a}}(278-3375)$ & $63.4(40.7-86)$ & Ahsan 2001 \\
\hline Northeastern India & - & - & - & $15-30$ & $\begin{array}{l}\text { Alfred \& Sati 1986, } \\
\text { 1990a; Alfred } 1992\end{array}$ \\
\hline Tripura, India & 6 & - & - & $300(300-400)$ & $\begin{array}{l}\text { Mukherjee } 1982 \text { cited in } \\
\text { Alfred \& Sati } 1992\end{array}$ \\
\hline Tripura, India & 2 & 1976-1983 & $600(300-1000)$ & & Mukherjee 1986 \\
\hline West Garo Hills, Meghalaya, India & 42 (survey) & - & - & $31(14-55)$ & Alfred \& Sati $1990 b$ \\
\hline Hollongapar, Assam, India & 7 & 2 months & - & $22(18-30)$ & Tilson 1979 \\
\hline Hollongapar, Assam, India & 3 & 3 months & $1136(973-1421)$ & $41.8(23.5-58)$ & Sankaran 2009 \\
\hline Eastern Assam, India & 6 & 12 months & $1116(654-1513)$ & $25.7(13.0-47.8)$ & Kakati 2004 \\
\hline Borajan RF, Assam & 2 & 6 months & $380.7(130-1000)$ & $8(5.4-10.5)$ & Kakati 1997 \\
\hline \multicolumn{6}{|l|}{ Eastern Hoolock Gibbon (H. leuconedys) } \\
\hline Lohit District, Arunachal Pradesh, India & - & - & $100-200$ & $100-200$ & Mukherjee et al. 1992 \\
\hline Nangkang Nature Park, Yunan, China & 1 & - & & ca.100 & Fan 2008 \\
\hline Nangkang Nature Park, Yunan, China & $2^{\mathrm{a}}$ & 14 months & $1162(345-2606)$ & 88.1 & Zhang et al. 2014 \\
\hline $\begin{array}{l}\text { Fragmented forest around Mehao WS, } \\
\text { Arunachal Pradesh, India }\end{array}$ & 2 & 11 months & $37.4(6.98-106.05)$ & $1.09-2.49$ & Present study \\
\hline Mehao WS, Arunachal Pradesh, India & 2 & 12 months & $\begin{array}{l}410.21(217.73- \\
775.17)\end{array}$ & $16.28-24.62$ & Present study \\
\hline
\end{tabular}


hoolock in isolated forest patches in NE India where the home range was recorded between 3-10.5 ha (Gittins \& Tilson, 1984; Kakati 1997; Kakati et al. 2009; Thampy et.al. 2009) (Table 5). The groups in contiguous forest have a comparatively stable home range which is within the range of other studied gibbon species including $H$. hoolock (e.g., Tilson 1979; Alfred \& Sati 1986; Alfred 1992; Ahsan 2001; Kakati 2004; Barlett 2007). The recent study on $\mathrm{H}$. leuconedys had claimed a higher home range in the Montane forests of China due to patchily distributed food resources than for most lowland gibbons (Zhang et al. 2014). Many researchers have also pointed out the effect of group size on the home range. The present study could not draw a clear conclusion regarding such affects as the study groups were almost of the same size ranging from 2-3 individuals in each group (Table 1 ).

There is a distinct seasonal pattern of home range used by all of the study groups with the highest contribution during the monsoon and pre-monsoon seasons in fragmented and contiguous forests respectively (Table 4). The reason for fragmented forests' groups preferring the monsoon season were very clear and thought to be the same DPL that is due to the minimal human interference in their range. Zhang et al. (2014) had reported the largest monthly home range in the month of May for $\mathrm{H}$. leuconedys in China. However, the results for the other seasons of his study did not conform with those of the present study. The reasons might be different in different forest types which influence monthly and seasonal home range. As fruit availability was more in the pre-monsoon season, groups of gibbons in contiguous forests move to greater extent to explore more patches.

In conclusion, the home range and daily path length of $\mathrm{H}$. leuconedys in the Lower Dibang Valley, Arunachal Pradesh has been highly affected by forest fragmentation or canopy discontinuity which makes habitat specialists' species (gibbons) more vulnerable and they become more accessible to hunting and predation by domestic dogs (Panor 2011). Thus, forest fragmentation ultimately is leading the population towards local extinction. These findings evoke the question of the long term survival of the gibbons in fragmented forests or unclassified state forest of Lower Dibang Valley District.

\section{REFERENCES}

Ahsan, F. (1994). Ecology of the Hoolock Gibbon (Hylobates hoolock) in Bangladesh. Unpublished PhD. Dissertation, University of Cambridge.

Ahsan, M.F. (2001). Socio-ecology of the Hoolock Gibbon (Hylobates hoolock) in two forests of Bangladesh, pp. 286-299. In: Chicago Zoological Society (ed.). The Aapes: Challenges for the 21st century. Brookfield Zoo, May 10-13, 2000, Conference Proceedings, Chicago Zoological Society, Brookfield, Illinois, U.S.A.

Alfred, J.R.B. (1992). The Hoolock Gibbon Hylobates hoolock. Primate Report 34: 65-69.

Alfred, J.R.B. \& J.P. Sati (1986). The gibbons with special reference to Hylobates hoolock, pp. 384-390. In: Majupuria, T.C. (ed.), Wildlife Wealth of India. Resources and Management. Tec Press Service, Bangkok.

Alfred, J.R.B. \& J.P. Sati (1990a). Behavioural study of the Hylobates hoolock Harlan, pp. 85-93. In: Mishra, R.R. \& K. Chatterjee (eds.). Current Trends in Environmental Biology. School of Life Sciences, Northeastern Hill University, Shillong.

Alfred, J.R.B. \& J.P. Sati (1990b). Survey and census of the hoolock gibbon in West Garo Hills, northeast India. Primates 31: 299-306; http://dx.doi.org/10.1007/BF02380951

Bartlett, T.Q. (1999). Feeding and ranging behavior of the Whitehanded Gibbon (Hylobates lar) in Khao Yai National Park, Thailand [PhD Dissertation]. Washington University, St. Louis, MO.

Bartlett, T.Q. (2007). The hylobatidae: small apes of Asia, pp. 274-289. In: Campbell, C.J., A. Fuentes, K.C. MacKinnon, M. Panger \& S.K. Bearder (eds.), Primates in Perspective. Oxford University Press, New York.

Bartlett, T.Q. (2009). Seasonal home range use and defendability in White-handed Gibbons (Hylobates lar) in Khao Yai National Park, Thailand, pp. 265-275. In: Lappan, S. \& D.J. Whittaker (eds.). The Gibbons: New Perspectives on Small Ape Socio-ecology and Population Biology. Springer, New York.

Borthakur, M. (1986). Weather and climate of Northeast India. The Northeast Geographer 18(1-2): 22-27.

Buzzard, P.J. (2006). Ranging patterns in relation to seasonality and frugivory among Cercopithecus campbelli, C. petaurista, and C. diana in the Taï Forest. International Journal Primatology 27(2): 559-573; http://dx.doi.org/10.1007/s10764-006-9028-1

Champion, H.G. \& S.K. Seth (1968). Revised Survey of Forest Types of India. Manager of Publications, New Delhi.

Chapman, C.A. (1988). Patterns of foraging and range use by three species of Neotropical Primates. Primates 29(2): 177-194; http:// dx.doi.org/10.1007/BF02381121

Chapman, C.A. \& L.J. Chapman (2000). Determinants of group size in primates: the importance of travel costs, pp. 24-42. In: Boinski, S. \& P.A. Garber (eds.). On The Move: How and Why Animals Travel in Groups. University of Chicago Press, Chicago.

Chetry, D., R. Chetry, A. Das, C. Loma \& J. Panor (2008). New distribution records for Hoolock leuconedys in India. Primate Conservation 23: 125-128.

Chetry, D., R. Chetry, K. Ghosh \& A.K. Singh (2010). Status of Eastern Hoolock Gibbon (Hoolock leuconedys) population in Mehao Wildlife Sanctuary in Arunachal Pradesh, India. Primate Conservation 25: 87-94.

Chetry, R. \& D. Chetry (2010). First record of Eastern Hoolock Gibbon in Assam, India. Primate Conservation 25: 95-97.

Chivers, D.J. (1984). Feeding and ranging in gibbons: a summary, pp. 267-281. In: Preushoft, H., D.J. Chivers, W.Y. Brockelman \& N. Creel (eds.). The Lesser Apes. Evolutionary and Behavioural Biology. Edinburgh University Press, Edinburgh.

Clutton-Brock, T.H. \& P.H. Harvey (1977). Species differences in feeding and ranging behavior in primates, pp. 585-590. In: CluttonBrock, T.H. (ed.). Primate Ecology: Studies of Feeding and Raging Behavior in Lemurs, Monkeys, and Apes. Academic, London.

Das, J. (2002). Socioecology of Hoolock Gibbon Hylobates hoolock hoolock (Harlan, 1834) in response to habitat change. PhD Thesis. Department of Zoology, Gauhati University, Guwahati, India.

Das, J., J. Biswas, P.C. Bhattacharjee \& S.M. Mohnot (2006). First distribution records of the Eastern Hoolock Gibbon (Hoolock hoolock leuconedys) from India. Zoos' Print Journal 21: 2316-2320; http://dx.doi.org/10.11609/JoTT.ZPJ.1530.2316-20

Di Fiore, A. (2003). Ranging behavior and foraging ecology of Lowland 
Woolly Monkeys (Lagothrix lagotricha poeppigii) in Yasuní Nationa Park, Ecuador. American Journal of Primatology 59: 47-66; http:// dx.doi.org/10.1002/ajp.10065

Ellefson, J. O. (1974). A natural history of the white-handed gibbon in the Malayan peninsular. pp. 1-136. In : Rumbaugh, D.M. (ed.), Gibbon and Siamang - Vol. 3. Karger, Basel.

Estrada, A. \& R. Coates-Estrada (1996). Tropical rain forest fragmentation and wild populations of primates at Los Tuxtlas, Mexico. International Journal of Primatology 17(5): 759-783; http://dx.doi.org/10.1007/BF02735263

Fan, P.F., H.S. Ai, H.L. Fei, D. Zhang \& S.D. Yuan (2013). Seasonal variation of diet and time budget of Eastern Hoolock Gibbons (Hoolock leuconedys) living in a northern montane forest. Primates 54: 137-146; http://dx.doi.org/10.1007/s10329-012-0336-0

Fan, P.F. \& X.L. Jiang (2008). Sleeping sites, sleeping trees, and sleeprelated behaviors of Black-crested Gibbons (Nomascus concolor jingdongensis) at Mt. Wuliang, central Yunnan, China. American Journal of Primatology 70: 153-160; http://dx.doi.org/10.1002/ ajp. 20470

Fan, P.F., W. Xiao, S. Huo, H.S. Ai, T.C. Wang \& R.T. Lin (2011). Distribution and conservation status of the Vulnerable Eastern Hoolock Gibbon Hoolock leuconedys in China. Oryx 45(1): 129-134; http://dx.doi.org/10.1017/S003060531000089X

Feeroz, M.M. \& M.A. Islam (1992). Ecology and Behaviour of Hoolock Gibbons of Bangladesh. MARC, Dhaka, 76pp.

Ganas, J. \& M.M. Robbins (2005). Ranging behavior of the Mountain Gorillas (Gorilla beringei beringei) in Bwindi Impenetrable National Park, Uganda: a test of the ecological constraints model. Behavioral Ecology and Sociobiology 58: 277-288.

Gautier-Hion, A., F. Bourlière, J.P. Gautier \& J. Kingdon (1988). A Primate Radiation: Evolutionary Biology of the African Guenons. Cambridge University Press, Cambridge, UK

Geissmann, T. (2007). Status reassessment of the gibbons: results of the Asian primate red list workshop 2006. Gibbon Journal 3: 5-15.

Geissmann, T., M.E. Grindley, L. Ngwe, S.A. Saw, N.A. Thet, B.H. Saw \& F. Momberg (2013). The Conservation Status of Hoolock Gibbons in Myanmar. Gibbon Conservation Alliance, Zürich, Switzerland.

Gittins, S.P. \& R.L. Tilson (1984). Notes on the ecology and behaviour of the Hoolock Gibbon, pp. 258-266. In: Preuschoft, H., D.J. Chivers, W.Y. Brockelman \& N. Creel (eds.). The Lesser Apes: Evolutionary and Behavioural Biology. Edinburgh University Press, Edinburgh.

Gittins, S.P. \& A.W. Akonda (1982). What survives in Bangladesh? Oryx 16: $275-281$.

Gittins, S.P. (1982). Feeding and ranging in the Agile Gibbon. Folia Primatologica 38: 39-71; http://dx.doi.org/10.1159/000156043

Groves, C.P. (1971). Geographic and individual variation in Bornean Gibbons, with remarks on the systematics of the subgenus Hylobates. Folia Primatologica 14: 139-153; http://dx.doi. org/10.1159/000155345

Harrison, M.J.S. (1983). Patterns of range use by the green monkey, Cercopithecus sabaeus, at Mt. Assirik, Senegal. Folia Primatologica 41: 157-179; http://dx.doi.org/10.1159/000156129

Hausfater, G. \& B.J. Meade (1982). Alternation of sleepinggroves by Yellow Baboons (Papio cynocephalus) as a strategy for parasite avoidance. Primates 23: 287-297; http://dx.doi.org/10.1007/ BF02381167

Islam, M.A. \& M.M. Feeroz (1992). Ecology of Hoolock Gibbon of Bangladesh. Primates 33: 451-464; http://dx.doi.org/10.1007/ BF02381149

Janson, C.H. \& M.L. Goldsmith (1995). Predicting group size in primates: Foraging costs and predation risks. Behavioura Ecology and Sociobiology 6: 326-336

Kakati, K. (1997). Food selection and ranging in the Hoolock Gibbon (Hylobates hoolock) in Borajan Reserve Forest, Assam. MSc Dissertation. Wildlife Institute of India, Dehradun, India.

Kakati, K. (2004). Impact on forest fragmentation on the hoolock gibbon in Assam, India. PhD Thesis, University of Cambridge Wildlife Research Group, Department of Anatomy, University of Cambridge, and Wolfson College, Cambridge, 212pp.
Kakati, K., R. Raghavan, R. Chellam, Q. Qureshi \& D.J. Chivers (2009). Status of Western Hoolock Gibbon (Hoolock hoolock) populations in fragmented forests of eastern Assam. Primate Conservation 24: 127-137.

Kaplin, B.A. (2001). Ranging behavior of two species of Guenons (Cercopithecus Ihoesti and C. mitis doggetti) in the Nyungwe Forest Reserve, Rwanda. International Journal of Primatology 22(4): 521548; http://dx.doi.org/10.1023/A:1010716001014

Kaul, R.N. \& K. Haridasan (1987). Forest types of Arunachal Pradesh - A preliminary study. Journal of Economic Taxonomy Botany 9: 379-389.

Kim, S., S. Lappan \& J.C. Choe (2011). Diet and ranging behavior of theendangered Javan Gibbon (Hylobates moloch) in submontanetropical rainforest. American Journal of Primatology 73: 270-280; http://dx.doi.org/10.1002/ajp.20893

Kinnaird, M.F. (1992). Variable resource defense by the Tana River Crested Mangabey. Behavioura Ecology and Sociobiology 31: 115122.

Laundre, J.W. \& B.L. Keller (1984). Home range size of coyotes: a critical review. Journal of Wildlife Management 48: 127-139.

Lovejoy, T.E., R.O. Bieregaard, A.B. Rylands, J.R. Malcolm, C.E. Quintela, L.H. Harper, Jr. K.S. Brown, A.N. Powell, G.V.N. Powell, H.O.R. Schubart \& M.B. Mays (1986). Edge and other effects of isolation on Amazon forest fragments, pp. 257-285. In: Soule, M.E. (ed.). Conservation Biology: The Science of Scarcity and Diversity. Sinauer Press, Sunderland.

Marsh, L.K. (2003). The nature of fragmentation, pp. 1-10. In: Marsh, L.K. (ed.). Primates in Fragments: Ecology and Conservation. Kluwer Academic/Plenum Publishers, New York.

McConkey K.R. \& D.J. Chivers (2007). Influence of gibbon rangingpatterns on seed dispersal distance and deposition site in a Bornean forest. Journal of Tropical Ecology 23: 269-275.

Milton, K. \& M.L. May (1976). Body weight, diet and home range area in primates. Nature 259: 459-462.

Milton, K. (1980). The Foraging Strategy of Howler Monkeys: A Study in Primate Economics. Columbia University Press, New York.

Mootnick, A. \& C.P. Groves (2005). A new generic name for the Hoolock Gibbon (Hylobatidae). International Journal of Primatology 26(4): 971-976; http://dx.doi.org/10.1007/s10764-005-5332-4

Morales, J.M., P.R. Moorcroft, J. Matthiopoulos, J.L. Frair, J.G. Kie \& R.A. Powell (2010). Building the bridge between animal movement and population dynamics. Philosophical Transactions of the Royal Society B: Biological Sciences 365: 2289-2301.

Mukherjee, R.P. (1982). Survey of non-human primates of Tripura, India. Journal of the Zoological Society India 34(1-2): 70-81.

Mukherjee, R.P. (1986). The ecology of the Hoolock Gibbon, H. hoolock, in Tripura, India, pp. 115-123. In: Else, J.G. \& P.C. Lee (eds.). Primate Ecology and Conservation. Cambridge University Press, Cambridge.

Mukherjee, R.P., S. Chaudhury \& A. Murmu (1992). Hoolock Gibbons (Hylobates hoolock) in Arunachal Pradesh, northeast India: The Lohit District. Primate Conservation 12(13): 31-33.

O'Brien, T.G. \& M.F. Kinnaird (1997). Behavior, diet, and movements of the Sulawesi Crested Black Macaque (Macaca nigra). International Journal of Primatology 18(3): 321-351; http://dx.doi. org/10.1023/A:1026330332061

Olupot, W., C.A. Chapman, P.M. Waser \& G. Isabirye-Basuta (1997). Mangabey (Cercocebus albigena) ranging patterns in relation to fruit availability and the risk of parasite infection in Kibale National Park, Uganda. American Journal of Primatology 43: 65-78.

Onderdonk, D.A. \& C.A. Chapman (2000). Coping with forest fragmentation: The primates of Kibale National Park, Uganda. International Journal of Primatology 21(4): 587-611; http://dx.doi. org/10.1023/A:1005509119693

Ostro, L.E. T., S.C. Silver, F.W. Koontz, T.P. Young \& R.H. Horwich (1999). Ranging behavior of translocated and established groups of Black Howler Monkeys Alouatta pigra in Belize, Central America. Biological Conservation 87: 181-190.

Overdorff, D.J. (1993). Ecological and reproductive correlates to range use in Red-bellied Lemurs (Eulemur rubriventer) and Rufous 
Lemurs (Eulemur fulvus rufus), pp. 167-178. In: Kappeler, P.M. \& J.U Ganzhorn (eds.), Lemur Social Systems and Their Ecological Basis. Plenum Press, New York.

Panor, J. (2011). Outings with hoolock of Delo. Zoos Print XXVI(12): 19-20.

Poulsen, J.R., C.J. Clark \& T.B. Smith (2001). Seasonal variation in the feeding ecology of the Grey-cheeked Mangabey (Lophocebus albigena) in Cameroon. American Journal of Primatology 54: 91105; http://dx.doi.org/10.1002/ajp.1015

Raemaekers, J.J. (1979). Ecology of sympatric gibbons. Folia Primatology 31: 227-245; http://dx.doi.org/10.1159/000155886

Sankaran, S. (2009). Social behaviour and duetting in Hoolock Gibbons in Gibbon Wildlife Sanctuary, Assam. Master's Thesis, Wildlife Science, Saurashtra University, Rajkot, 47pp.

Sarma, K., A. Kumar, C.M. Krishna, O.P. Tripathi \& P.R. Gajurel (2013). Ground feeding observations on Corn (Zea mays) by Eastern Hoolock Gibbon (Hoolock leuconedys). Current Science 104: 587-589.

Sarma, K., M. Krishna \& A. Kumar (2015). Fragmented populations of Eastern Hoolock Gibbon Hoolock leuconedys in Lower Dibang Valley District, Arunachal Pradesh, India. Oryx 49: 133-139; http://dx.doi. org/10.1017/S0030605312001299

Sigg, H. \& A. Stolba (1981). Home range and daily march in a Hamadryas Baboon troop. Folia Primatologica 36: 40-75; http:// dx.doi.org/10.1159/000156008

Thampy, G., J. Das \& W.S. McGraw (2004). Feeding and ranging of Hoolock Gibbons (Hylobates hoolock) in the Borajan Wildlife Sanctuary, Assam, India. American Journal of Physical Anthropology Supplement 38: 194
Tilson, R.L. (1979). Behaviour of Hoolock Gibbon (Hylobates hoolock) during different seasons in Assam, India. Journal of the Bombay Natural History Society 76(1): 1-15.

Tutin, C.E.G \& L. White (1999). The recent evolutionary past of primate communities: Likely environmental impacts during the past three millennia, pp. 220-236. In: Fleagle, J.G., C. Janson \& K.E. Reed (eds.). Primate Communities. Cambridge University Press, Cambridge.

Wallace, R.B. (2006). Seasonal variations in Black-faced Black Spider Monkey (Ateles chamek) habitat use and ranging behavior in a southern Amazonian tropical forest. American Journal of Primatology 68: 313-332; http://dx.doi.org/10.1002/ajp.20227

Whitten, A.J. (1982). Home range use by Kloss Gibbons (Hylobates klossii) on Siberut Island, Indonesia Animal Behaviour 30: 182-198; http://dx.doi.org/10.1016/S0003-3472(82)80253-4

Zhang, D., H.L. Fei, S.D. Yuan, W.M. Suo, Q.Y. Ni, L.W. Cui \& P.F. Fan (2014). Ranging behavior of Eastern Hoolock Gibbon (Hoolock leuconedys) in a northern montane forest in Gaoligongshan, Yunnan, China. Primates 55: 239-247; http://dx.doi.org/10.1007/ s10329-013-0394-y

Zhou, Q.H., C.M. Huang, Y.B. Li \& X.W. Cai (2007). Ranging behavior ofthe Franc, ois' Langur (Trachypithecus francoisi) in the FusuiNature Reserve, China. Primates 48: 320-323; http://dx.doi.org/10.1007/ s10329-006-0027-9 